\title{
Perspectives of Biobutanol Production and Use
}

\author{
Petra Patakova, Daniel Maxa, Mojmir Rychtera, Michaela Linhova, \\ Petr Fribert, Zlata Muzikova, Jakub Lipovsky, Leona Paulova, \\ Milan Pospisil, Gustav Sebor and Karel Melzoch \\ Institute of Chemical Technology Prague \\ Czech Republic
}

\section{Introduction}

Nowadays, with increasing hunger for liquid fuels usable in transportation, alternatives to crude oil derived fuels are being searched very intensively. In addition to bioethanol and ethyl or methyl esters of rapeseed oil that are currently used as bio-components of transportation fuels in Europe, other options are investigated and one of them is biobutanol, which can be, if produced from waste biomass or non-food agricultural products, classified as the biofuel of the second generation. Although its biotechnological production is far more complicated than bioethanol production, its advantages over bioethanol from fuel preparation point of view i.e. higher energy content, lower miscibility with water, lower vapour pressure and lower corrosivity together with an ability of the producer, Clostridium bacteria, to ferment almost all available substrates might outweigh the balance in its favour. The main intention of this chapter is to summarize briefly industrial biobutanol production history, to introduce the problematic of butanol formation by clostridia including short description of various options of fermentation arrangement and most of all to provide with complex fermentation data using little known butanol producers Clostridium pasteurianum NRRL B-592 and Clostridium beijerinckii CCM 6182. A short overview follows concerning the use of biobutanol as a fuel for internal combustion engines with regard to properties of biobutanol and its mixtures with petroleum derived fuels as well as their emission characteristics, which are illustrated based on emission measurement results obtained for three types of passenger cars.

\section{Theoretical background}

\subsection{History of industrial biobutanol production}

The initiation of the industrial acetone-butanol-ethanol (ABE) production by Clostridium fermentation is connected with the chemist Chaim Weizmann, working at the University of Manchester UK, who wished to make synthetic rubber containing butadiene or isoprene units from butanol or isoamyl alcohol and concentrated his effort on the isolation of microbial producers of butanol. Further, the development of acetone-butanol process was accelerated by World War I when acetone produced by ABE fermentation from corn in Dorset, UK was used for cordite production. However in 1916, the German blockade hampered the supply of grain and the production was transferred to Canada and later with the entry of the United States to the war, two distilleries in Terre Haute were adapted to 
acetone production. After the war, the group of American businessmen bought Terre Haute plant and restored the production in 1920; at that time butanol was appreciated as solvent for automobile lacquers. Subsequently, with decreasing price of molasses new solventogenic strains were isolated and first plant using this feedstock was built at Bromborough in England near the port, in 1935. In 1936 the Weizmann patent expired and new acetonebutanol plants were erected in U.S.A., Japan, India, Australia and South Africa using usually molasses as the substrate. The Second World War again accelerated the process development and acetone became the most required product; the plant at Bromborough was expanded and semi continuous way of fermentation which cut the fermentation time to 30$32 \mathrm{~h}$ was accomplished here together with continuous distillation. At the end of the war, two thirds of butanol in U.S.A. was gained by fermentation but rise of petrochemical industry together with increasing price of molasses that started to be used for cattle feeding caused gradual decline of industrial acetone-butanol fermentation. Most of the plants in Western countries were closed by 1960 with the exception of Germiston factory in South Africa where cheap molasses and coal enabled to keep the process till 1983 (Jones \& Woods, 1986). In addition to Western countries, the production of acetone and butanol was also supported in the Soviet Union. Here, in Dukshukino plant, in 1980s, the process was operated as semi continuous in multi-stage arrangement with possibility to combine both saccharidic and starchy substrates together with small portion (up to 10\%) of lignocellulosic hydrolyzate and continuous distillation (Zverlov et al., 2006). In China, industrial fermentative acetone and butanol production began around 1960 and in 1980s there was the great expansion of the process. Originally, batch fermentation was changed to semi continuous 4 -stage process in which the fermentation cycle was reduced to $20 \mathrm{~h}$, the yield was about 35-37\% from starch and the productivity was 2.3 times higher in comparison with batch process (Chiao \& Sun, 2007). At the end of $20^{\text {th }}$ century the most of Chinese plants were probably closed (Chiao \& Sun, 2007) but now hundred thousands of tons of acetone and butanol per year are produced by fermentation in China (Ni \& Sun, 2009).

Industrial production of $\mathrm{ABE}$ in the former Czechoslovakia started with a slight delay comparing with other already mentioned countries. Bacterial cultures were isolated, selected and tested for many years by professor J. Dyr, head of the Department of Fermentation Technology of the Institute of Chemical Technology in Prague who lead a small research team and preparatory works for the plant design (Dyr \& Protiva, 1958). Acetone - butanol plant was fully in operation from 1952 till 1965. The main raw materials were firstly potatoes which were later changed for rye. Various bacteria cultures (all were classified as Clostridium acetobutylicum) were prepared for several main crops (potatoes, rye, molasses) which increased flexibility of the production. Annual production of solvents increased from year to year but did not exceed 1000 tons. Concentration of total solvents in the broth varied around 17-18 g. $\mathrm{L}^{-1}$. Process itself was run as batch, $\mathrm{pH}$ was never controlled, propagation ratio in large fermentation section was $1: 35$. The whole fermentation time was on average $36-38 \mathrm{~h}$. Critical point for each fermentation was "break" in acidity after which started a strong evolution of gases and solvents. In case of potatoes and rye there were no nutrients supplied to the fermentation broth. The only process necessary for the pre-treatment of the raw materials of starch origin was their steaming under pressure in Henze cooker. Initial concentration of starch ranges from 4.5 to $5 \%$ wt. In spite of keeping all sanitary precaution (similarly today's GMP) two types of unexpected failures occurred. Firstly it was contamination by bacteriophage (not possible to analyze it in those times) which appeared approx. three times during the lifetime and always was followed by a total sanitation and complete change of the producing strain. Secondly there appeared another unexpected 
event, i.e. a final turn to a complete acidification without initiation of solvent production indicated by a spore creation. This situation appeared in the range from 1 to $4 \%$ of the total number of batches.

\subsection{Principle of acetone-butanol-ethanol (ABE) fermentation}

The butanol production through acetone-butanol-ethanol (ABE) fermentation is an unique feature of some species of the genus Clostridium; the most famous of them are strains of C.acetobutylicum, C.beijerinckii and C.saccharoperbutylacetonicum but others with the same ability exist, too. Together with all Clostridium bacteria, solvent producers share some common characteristics like rod-shaped morphology, anaerobic metabolism, formation of heat resistant endospores, incapability of reduction of sulphate as a final electron acceptor and $\mathrm{G}^{+}$type of bacterial cell wall (Rainey et al., 2009).

$\mathrm{ABE}$ fermentation consists of two distinct phases, acidogenesis and solventogenesis. While the first one is coupled with growth of cells and production of butyric and acetic acids as main products the second one, started by medium acidification, can be characterized by initiation of sporulation and metabolic switch when usually part of formed acids together with sugar carbon source are metabolized to 1-butanol and acetone. The biphasic character of $\mathrm{ABE}$ fermentation coupled with alternation of symmetric and asymmetric cell division, first mentioned by Clarke et al., (1988), is shown in Fig. 1. In the batch cultivation, first acidogenic phase is connected with internal energy generation and accumulation and also cells growth while second solventogenic phase is bound with energy consumption and sporulation. The tight connection of sporulation and solvents production was proved by finding a gene spo0A responsible for both sporulation and solvent production initiation (Ravagnani et al., 2000).

Metabolic pathway leading to solvents production and originating in Embden-MayerhofParnas (EMP) glycolysis is shown in Fig.1, too. Pentoses unlike hexoses are converted to fructose-6-phosphate and glyceraldehyde-3-phosphate prior to their entrance to EMP metabolic pathway. Major products of the acidogenic phase - acetate, butyrate, $\mathrm{CO}_{2}$ and $\mathrm{H}_{2}$ are usually accompanied by small amounts of acetoin and lactate (not shown in Fig.1). The onset of solvents production is stimulated by accumulation of acids in cultivation medium together with $\mathrm{pH}$ drop. Butanol and acetone are formed partially from sugar source and partially by reutilization of the formed acids; and simultaneously a hydrogen production is reduced to a half in comparison with the acidogenic phase (Jones \& Woods, 1986; Lipovsky et al., 2009). Functioning of all enzymes involved in the butanol formation has been reviewed, recently (Gheslaghi et al., 2009). Unfortunately, butanol is highly toxic to the clostridia and its stress effect causes complex response of the bacteria in which more than 200 genes regulating membrane composition, cell transport, sugar metabolism, ATP formation and other functionalities are involved and complicate any effort to increase butanol resistance (Tomas et al., 2004).

Solventogenic clostridia are known for their capabilities to utilize various mono-, di-, oligoand polysaccharides like glucose, fructose, xylose, arabinose, lactose, saccharose, starch, pectin, inulin and others but usually the specific strain is not able to utilize efficiently all of named substrates. Although all genes of cellulosome were identified in C.acetobutylicum ATCC 824 genome, the whole cellulosome is not functional what results in incapability of cellulose utilization (Lopez-Contreras et al., 2004). At first, starchy substrates like corn and potatoes were used for $\mathrm{ABE}$ fermentation but later blackstrap molasses became the preferential feedstock. Nowadays, a lot of researchers aim to use lignocellulosic hydrolyzates which, if available at a reasonable price and quality (no inhibitors), would be 
ideal feedstock for this process because clostridia can utilize diluted solutions of various hexoses, pentoses, disaccharides and oligosacharides efficiently.
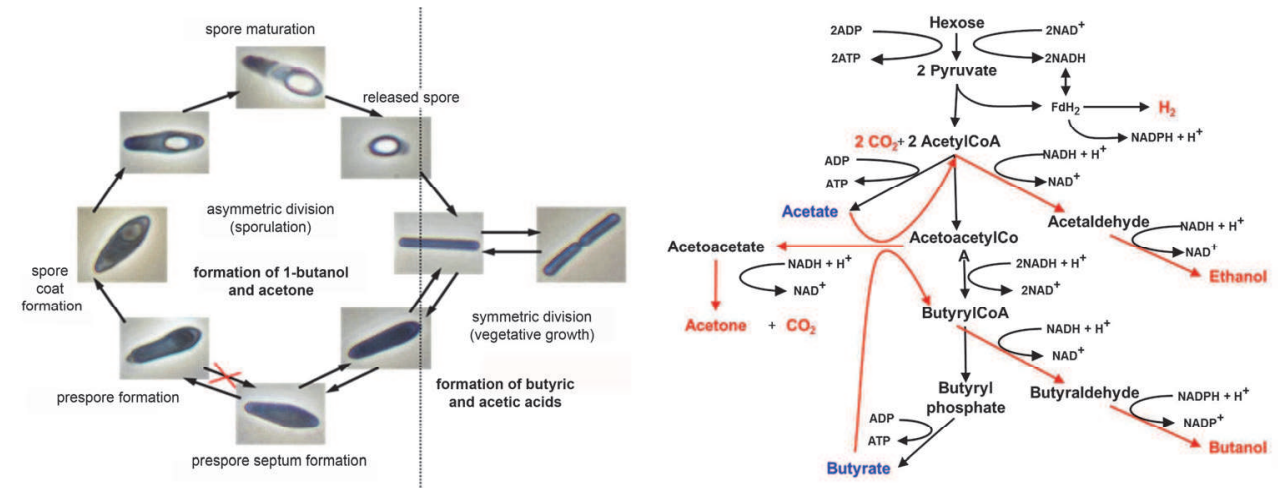

Fig. 1. Life cycle of solventogenic clostridia and simplified metabolic scheme

\subsubsection{Challenges of butanol production}

Production of biobutanol by clostridia is not straightforward process and 1-butanol is neither a typical primary metabolite, the formation of which is connected with cells growth, nor a typical secondary metabolite like antibiotics or pigments. The metabolic switch from acido- to solventogenesis, regulation of which is usually connected with sporulation initiation, does not need to happen necessarily during the fermentation. Actually, when cells are well nourished and their growth rate approaches its maximum then cells reproduce and form only acids; this state has been many times observed in continuous cultivations (Ezeji et al., 2005) but sometimes it can occur even in batch cultivation as so-called "acid crash" (Maddox et al., 2000; Rychtera et al., 2010) which was generally ascribed to fast acetic and butyric acids formation. The proposed acid crash prevention was careful $\mathrm{pH}$ control or metabolism slowdown by lowering cultivation temperature (Maddox et al., 2000). However, very recently the novel possible explanation of this phenomenon has been revealed in intracellular accumulation of formic acid by C.acetobutylicum DSM 1731 (Wang et al., 2011). If acid crash is the phenomenon that usually happens at random in the particular fermentation, so-called strain degeneration is a more serious problem when the production culture loses either transiently or permanently its ability to undergo the metabolic shift and to produce solvents. The reliable prevention of the degeneration is maintaining the culture in the form of spore suspension (Kashket \& Cao, 1995). A cause of degeneration was investigated in many laboratories using various clostridial strains and therefore also with different results. The degeneration of C.acetobutylicum ATCC 824 is probably caused by loss of its mega plasmid containing genes for both sporulation and solvents production (Cornillot et al., 1997) but mechanism and reason of this degeneration were not offered by this study. Actually the authors (Cornillot et al., 1997) compared wild-type strain C.acetobutylicum ATCC 824 with isolated degenerated mutants. It is questionable how often or under which conditions the degeneration of C.acetobutylicum ATCC 824 happens because in the past, it was reported 218 passages of vegetative C.acetobutylicum ATCC 824 cells did not almost influence their solvents formation (Hartmanis et al., 1986). The cells of C.saccharoperbutylacetonicum N1-4 degenerated when quorum sensing mechanism in the 
population was impaired (Kosaka et al., 2007). The very detailed study of C.beijerinckii NCIMB 8052 degeneration disclosed two different degeneration causes: involvement of global regulatory gene and defect in NADH generation (Kashket \& Cao, 1995). It seems probable that degeneration has no single reason and if other strains were studied different reasons would be found.

ABE industrial fermentation was probably the first process that had to cope with bacteriophage infection of producing microorganism. The first severe bacteriophage attack was reported from Terre Haute plant in the U.S.A. in 1923 and the problems occurred at fermentation of corn by Clostridium acetobutylicum (the solvents yield was decreased by half for a year). From that time, Clostridium strains used for either starch or saccharose fermentations were attacked by various both lysogenic and lytic bacteriophages what was documented in the literature. The ABE plant in Germiston in South Africa faced to confirmed bacteriophage infection 4- times in its 46-year history (plus two unconfirmed cases). Till now, the best solution in battle against Clostridium bacteriophages seems to be the prevention i.e. good process hygiene, sterilization, decontamination and disinfection (Jones et al., 2000).

Lactic acid bacteria represent the most common type of contamination having very similar requests for cultivation conditions (temperature, $\mathrm{pH}$, anaerobiosis, composition of cultivation media) as clostridia and grow faster. These bacteria can cause not only losses in solvents yield but also can hamper the metabolic switch of clostridia because formed lactic acid over-acidifies the medium and poisons the clostridia in higher concentration. Other contaminants like Bacillus bacteria or yeast are encountered only scarcely (Beesch, 1953).

\subsection{Novel approaches toward biobutanol production}

In the past industrial applications, batch fermentation was a usual way how to produce biobutanol due to arrangement simplicity and attaining maximum biobutanol concentration, given by the used strain and cultivation medium, at the end of fermentation. Fed-batch fermentation can be regarded as modification of the batch process offering slight productivity increase by reduction of lag growth phase. However, taking into account possible industrial scale of the process, the preferential process arrangement is continuous ABE fermentation due to a lack of so called "dead" operation times. Nevertheless, its accomplishment in single bioreactor e.g. as chemostat is not usually easy because of biphasic process character when butanol production is not connected with growth directly (see Fig. 1). Theoretically, clostridial culture behaviour under chemostat cultivation conditions should follow an oscillation curve when acidogenesis is coupled with cell multiplication and decrease of substrate concentration. On the contrary, solventogenesis is coupled with decrease of specific growth rate due to sporulation what leads to cells wash-out and increase of substrate concentration in the medium. These two states should cycle regularly (Clarke et al., 1988) but in practice, irregular cycling with various depths of individual amplitudes is more probable as demonstrated several times (S.M. Lee et al., 2008). Moreover, chemostat cultivation conditions induce selection pressure on the microbial culture favouring nonsporulating, quickly multiplying cells what may cause culture degeneration i.e. the loss of the culture ability to produce solvents (Ezeji et al., 2005).

However, there are other options, tested in laboratory scale, how to arrange continuous ABE fermentation like multi-stage process splitting clostridial life cycle into at least two vessels, where first smaller bioreactor serves mainly for cells multiplication under higher dilution rate and in the second bigger bioreactor, actual solventogenesis takes place (Bahl et al., 
1982). In addition, battery of bioreactors working in batch, fed-batch or semi-continuous regime ensuring continuous butanol output can also be considered continuous fermentation (Ni \& Sun, 2009; Zverlov et al., 2006).

ABE fermentation in any regime can be combined with cells immobilization performed by different methods - entrapment in alginate (Largier et al., 1985), use of membrane bioreactor (Pierrot et al., 1986) or cells adsorption on porous material (S.Y. Lee et al., 2008; Napoli et al., 2010). Recently, final report of the US DOE grant (Ramey \& Yang, 2004) has revealed a novel approach toward ABE fermentation. The principle of this solution is two step butanol production employing two microorganisms; at first Clostridium tyrobutyricum produces mainly butyric acid which is consumed by second microorganism Clostridium acetobutylicum and utilized for butanol production. The authors claimed they reached $50 \%$ yield of butyric acid in the first phase and $84 \%$ yield of butanol from butyrate. However, a pilot and a production plant planned for year 2005 have not been realized, yet. Nevertheless, this way of butanol production is still under research in U.S.A. (Hanno et al., 2010), focusing mainly on solventogenic clostridia that are capable of butyrate utilization for butanol production.

One of the main constraints of biotechnological butanol production is its low final concentration in fermented cultivation media caused by its severe toxicity toward producing cells. Average butanol concentration, stable reached in Germiston plant in South Africa, was 13 g.L-1 (Westhuizen et al., 1982). Although higher butanol concentration (about 20 g.L-1) can be attained using e.g. mutant strain C.beijerinckii BA101 (Qureshi \& Blaschek, 2001a) cost of distillation separation is still high. Therefore efficient preconcentration methods applied either after the fermentation or more often during the fermentation are being searched now. Moreover, if such separation method is integrated with fermentation process it will increase amount of utilized substrate by alleviating product toxicity. Preferential separation methods in this context seem to be gas stripping (Ezeji et al., 2003), adsorption on zeolites or pervaporation (Oudshoorn et al., 2009).

\section{Experience with biobutanol fermentation in ICT Prague}

Most of work was performed with the strain Clostridium pasteurianum NRRL B-592 which differed from usually employed solvent producing clostridia significantly, especially in sooner onset of solvents production i.e. during exponential growth phase. The strain was also chosen because of its properties i.e. stable growth and solvents production, robustness regarding minor changes in cultivation conditions and resistance toward so-called strain degeneration. Nevertheless in some cases, other, more typical solventogenic strains, C.acetobutylicum DSM 1731 and C.beijerinckii CCM 6182 were used, too.

Compositions of cultivation media, strains maintenance, description of cultivation, used analytical methods and expressions describing calculation of fermentation parameters i.e. yield and productivity for batch, fed-batch and continuous fermentations are given in Patakova et al., (2009 and 2011a).

\subsection{Methods of ABE study}

Despite complex process character, fermentation control, which is of key importance, relies only on few on-line measurable values like $\mathrm{pH}$ or redox potential of the medium and off-line determined concentrations of substrate(s), biomass and metabolites. In order to understand the process better and to improve fermentation control, fluorescence labelling of selected traits together with microscopy and flow cytometry was applied. Flow cytometry, as high- 
throughput, multi-parametric technique capable of analysis of heterogenic populations at the level of individual cells, has recently been used for description of clostridial butanol fermentations for the first time, but in totally different context (Tracy et al., 2008).

\subsubsection{Use of fluorescent alternative of Gram staining for discrimination of acidogenic and solventogenic clostridial cells}

The detailed description of the method development, particular application conditions and its use were published by Linhova et al., (2010a). The main idea of the staining is based on fact that clostridia are usually stained according to Gram as $\mathrm{G}^{+}$after germination from spores (motile, juvenile cells) and as $\mathrm{G}^{-}$when the cells started to sporulate. The change in Gram staining response corresponds to metabolic switch from acids to solvents formation and also with an alteration in a cell membrane composition i.e. thinning of peptidoglycan layer (Beveridge, 1990). Therefore the cells of C.pasteurianum were labelled with a combination of fluorescent probes, hexidium iodide (HI) and SYTO 13 that can be considered a fluorescent alternative of Gram staining. Cells of C.pasteurianum forming mainly acids fluoresced bright orange-red as $\mathrm{G}^{+}$bacteria and the solvent producing, sporulating cells exhibited green-yellow fluorescence as $G^{-}$bacteria (see Fig.2). The red colour of labelled young cells was a result of a fact that green fluorescence of SYTO13 was quenched by that of HI while bright green-yellow colour of sporulating and/or old cells was caused by staining only by SYTO13 when HI did not permeate across the cell wall. Jones et al., (2008) used different combination of dyes (propidium iodide and SYTO 9) for labelling C.acetobutylicum ATCC 824 during time course of batch cultivation but attained the same conclusion.
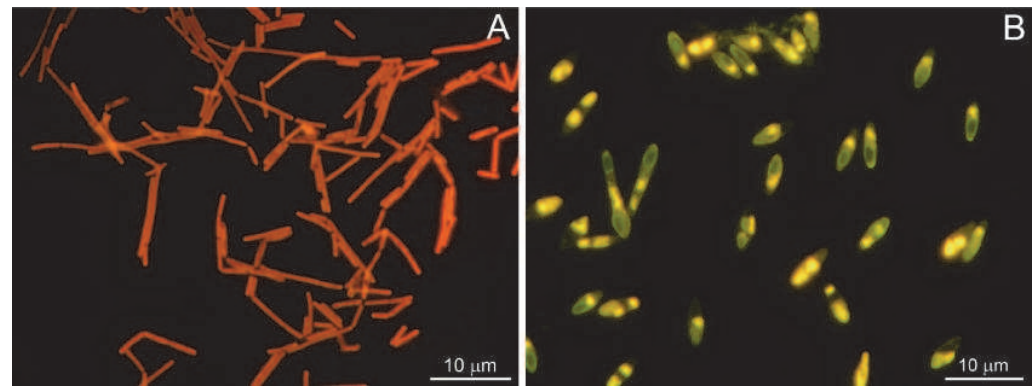

Fig. 2. C.pasteurianum cells stained with hexidium iodide and SYTO 13 in acidogenic (A) and solventogenic (B) metabolic phases

Then, flow cytometry enabling quantification of fluorescent intensities of labelled clostridial populations was used for monitoring of physiological changes during fed-batch cultivation (Linhova et al., 2010a). For flow cytometry measurement, the cells were stained only by $\mathrm{HI}$ and the signal of fluorescent intensity acquired in a channel FL3 (red colour) was related to forward scatter signal (FSC) which corresponded to cell size in order to gain data independent on cell size. The data measured for C.pasteurianum were compared with those for typical $\mathrm{G}^{+}$and $\mathrm{G}^{-}$bacteria i.e. for Bacillus megatherium and Escherichia coli and there was a striking difference between the values of FL3/FSC for C.pasteurianum on one hand and those for B.megatherium and E.coli on the other hand. While the values for B.megatherium $\left(\mathrm{G}^{+}\right)$and E.coli (G-) oscillated \pm 0.1 and \pm 0.2 , respectively, in time course of $32 \mathrm{~h}$ in which they were sampled, the values for C.pasteurianum dropped from 3.1 to 0.8 during the cultivation. It was 
also evident that acidogenic phase had a very short duration and both metabolic phases overlapped. Further experiments are necessary to assess unambiguously the acquired data, however it is tempting to hypothesize that C.pasteurianum NRRL B-598 has a different pattern of acids and solvents formation when solvents production is connected rather with exponential growth phase than the well-known solventogenic strain C.acetobutylicum ATCC 824 in which solvents production is generally assembled with stationary growth phase.

\subsubsection{Use of flow cytometry for viability determination of clostridia}

As to perform $\mathrm{ABE}$ fermentation means to handle clostridial population in different stages of the life cycle (see Fig. 1), determination of share of metabolically active i.e. vital cells in the population, is very important. Based on testing of various fluorescent viability probes with different principles of functioning, bisoxonol (BOX) was chosen as a convenient dye for C.pasteurianum viability determination (Linhova et al., 2010b). BOX stains depolarized cells with destroyed membrane potential i.e. nonviable cells. When the cells were fixed by $5 \mathrm{~min}$ boiling, whole population was labelled (Fig.3b) but in case of growing population (Fig.3a) most of cells remained non-stained. After optimization of staining conditions, flow cytometry was used for determination of culture viability (see Fig.4).
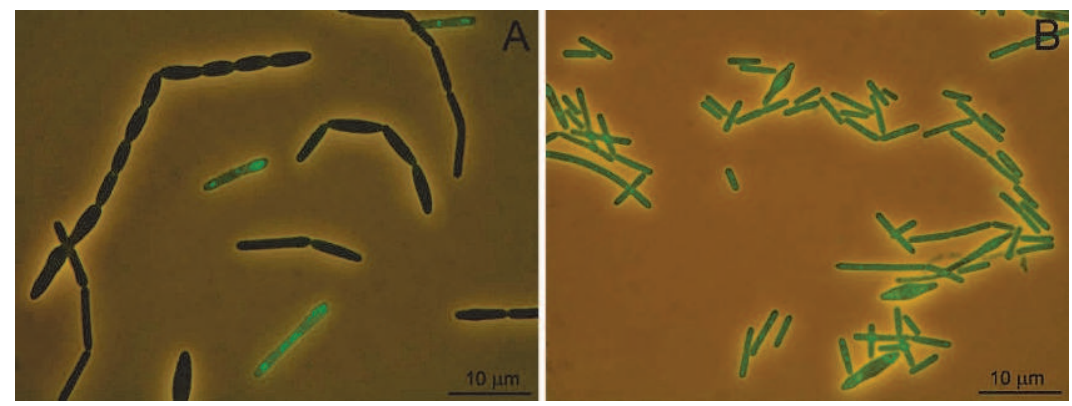

Fig. 3. BOX stained viable (A) and fixed i.e. nonviable (B) cells of C.pasteurianum
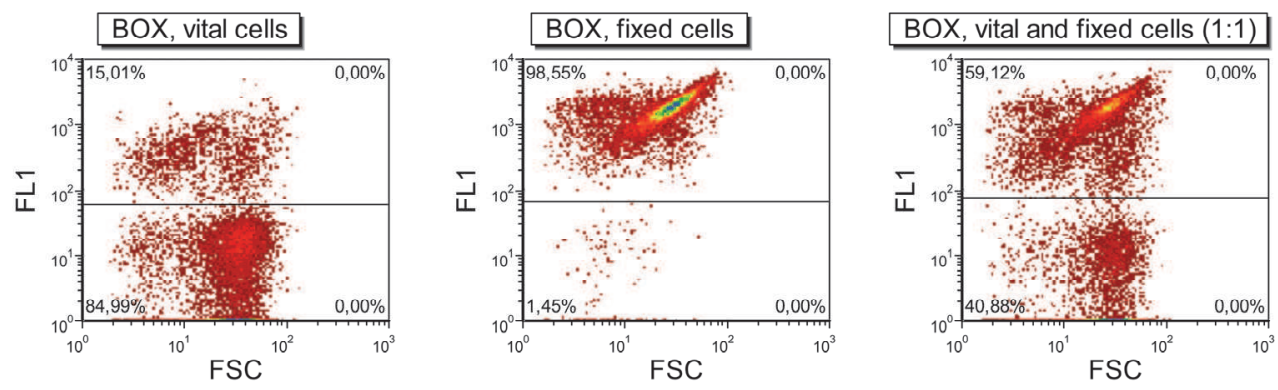

Population of viable cells in the left dot-plot diagram can be seen under the gate (in lower half of the diagram). In upper half of the left diagram, there are rests of cells after spores germination and sporulating cells, the share of which does not exceed $15 \%$.

Fig. 4. Dot-plot diagrams after BOX labelling of C.pasteurianum populations of live (1), fixed (2) and mixture of live and fixed cells (3) 
Then the method was used for viability determination during batch cultivation (see Fig.5). Bioreactor was inoculated with spore suspension after heat shock that induced spores to grow and killed present vegetative cells. After the heat shock, the viability at the beginning of the fermentation was very low (Fig. 5B). In the exponential growth phase viability increased to $\sim 78 \%$, as expected. With glucose depletion (Fig. $5 \mathrm{~B}$ ) and reaching the highest concentration of 1-butanol (7.5 g.L-1 see Fig.5A), the viability began to decrease. Relatively rapid viability decline at nutrient depletion conditions has already been observed by Novo et al., (1999) and Jepras et al., (1995) for S. aureus, E. coli and P. aeruginosa. They observed membrane potential decreased within a few minutes after removal of energy resources. Moreover, in our case, elevated 1-butanol concentration contributed to viability decline, too
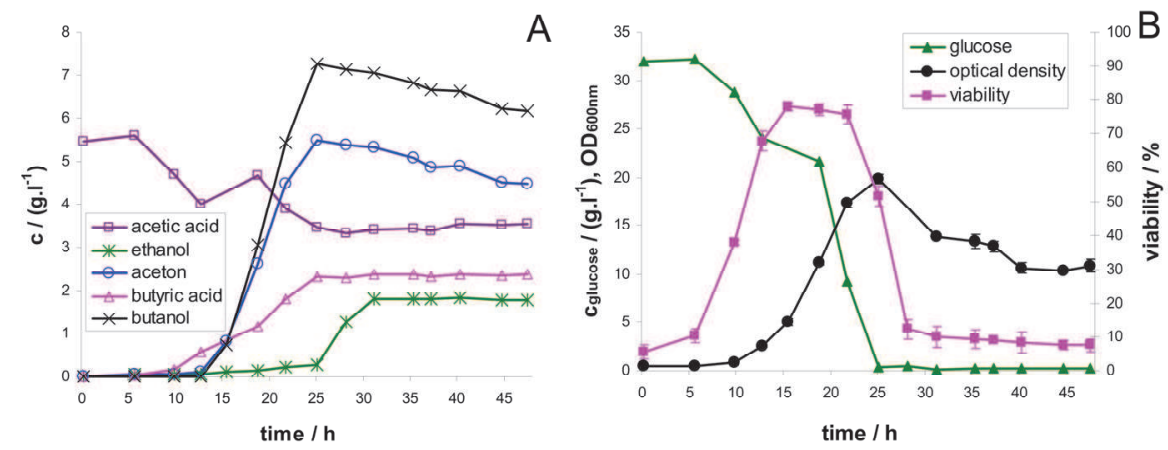

Fig. 5. Comparison of viability determination with fermentation data during batch cultivation of C.pasteurianum

\subsection{Feedstock comparison}

Based on screening in flask fermentations performed in an anaerobic chamber, every feedstock (sugar beet, corn and glucose) was matched with appropriate Clostridium strain regarding to yield and productivity values. Sugar beet is a crop grown in the Czech Republic for the last 160 years which provides high yields and can be used in the non food field for the biofuel production. In fact, non-food utilization of sugar beet is already running in CR but only bioethanol is produced in this way in Agroethanol TTD. Regarding corn, its main portion is grown for cattle feeding in CR but at the same time, the size of cattle herds diminishes every year. As the important goals of the biofuels production are, beside others, also the support of farmers and maintenance of arable land areas, corn can be seen as an energetic crop, too. Glucose was taken as feedstock on assumption glucose cultivation medium can be seen as a very simple model of lignocellulosic material hydrolyzate the use of which is supposed in future.

A comparison of butanol production using corn, sugar beet juice and glucose together with relevant strains is provided in Table 1 and sugar beet seems to be the preferable option according to the presented parameters. It is also noteworthy to look at fermentation courses in all compared cases. Fermentation of corn by C.acetobutylicum was running with textbooklike biphasic behaviour, when at first acids were formed and in the second solventogenic phase coupled with sporulation a reutilization of acids occurred. However, both fermentation of sugar beet juice by C.beijerinckii and fermentation of glucose by 
C.pasteurianum differed from this "typical" course by start of butanol formation during exponential growth phase (both cases) and almost no reutilization of acids (C.pasteurianum).

\begin{tabular}{|c|c|c|c|c|c|c|}
\hline species & substrate & $\mathrm{B}\left(\mathrm{g} . \mathrm{L}^{-1}\right)$ & $\begin{array}{c}\mathrm{ABE} \\
\left(\mathrm{g} . \mathrm{L}^{-1}\right)\end{array}$ & $\begin{array}{c}\mathrm{Y}_{\mathrm{ABE} / \mathrm{S}} \\
(\%)\end{array}$ & $\mathrm{Y}_{\mathrm{B} / \mathrm{S}}(\%)$ & $\mathrm{P}_{\mathrm{ABE}}\left(\mathrm{g} . \mathrm{L}^{-1} \cdot \mathrm{h}^{-1}\right)$ \\
\hline C.beijerinckii & $\begin{array}{c}\text { sugar beet } \\
\text { juice }\end{array}$ & 11.6 & 16.2 & 37 & 26 & 0.40 \\
\hline C.acetobutylicum & corn & 9.6 & 14.4 & 27 & 18 & 0.20 \\
\hline C.pasteurianum & glucose & 7.3 & 11.8 & 35 & 18 & 0.23 \\
\hline
\end{tabular}

Abbreviations B, ABE, YABE/S, YB/S, PABE stand for butanol, total solvents amount, yield of total solvents, yield of butanol and productivity of solvents formation.

Table 1. Comparison of bioreactor cultivations using different substrates and strains

Overall balances of mentioned fermentation courses can be expressed in form of equations (1-3). Similar expression of products in numbers has already been published (see Equation 4) by Jones \& Woods (1986) where this equation reflected average results achieved with C.acetobutylicum and C.beijerinckii strains published in literature till 1986. In the equations (14), $\mathrm{C}_{12} \mathrm{H}_{22} \mathrm{O}_{11}, \mathrm{C}_{6} \mathrm{H}_{12} \mathrm{O}_{6}, \mathrm{C}_{4} \mathrm{H}_{10} \mathrm{O}, \mathrm{C}_{3} \mathrm{H}_{6} \mathrm{O}, \mathrm{C}_{2} \mathrm{H}_{6} \mathrm{O}, \mathrm{C}_{2} \mathrm{H}_{4} \mathrm{O}_{2}, \mathrm{C}_{4} \mathrm{H}_{8} \mathrm{O}_{2}$ stand for saccharose, glucose, butanol, acetone, ethanol, butyric acid and acetic acid, respectively.

Butanol production from saccharose by C.beijerinckii:

$$
\begin{aligned}
1.00 \mathrm{C}_{12} \mathrm{H}_{22} \mathrm{O}_{11} \rightarrow & 1.22 \mathrm{C}_{4} \mathrm{H}_{10} \mathrm{O}+0.60 \mathrm{C}_{3} \mathrm{H}_{6} \mathrm{O}+0.04 \mathrm{C}_{2} \mathrm{H}_{6} \mathrm{O}+0.25 \mathrm{C}_{2} \mathrm{H}_{4} \mathrm{O}_{2} \\
& +0.20 \mathrm{C}_{4} \mathrm{H}_{8} \mathrm{O}_{2}+1.60 \mathrm{CO}_{2}+0.80 \mathrm{H}_{2}
\end{aligned}
$$

Butanol production from corn (expressed as glucose) by C.acetobutylicum:

$$
\begin{aligned}
1.00 \mathrm{C}_{6} \mathrm{H}_{12} \mathrm{O}_{6} \rightarrow & 0.42 \mathrm{C}_{4} \mathrm{H}_{10} \mathrm{O}+0.21 \mathrm{C}_{3} \mathrm{H}_{6} \mathrm{O}+0.04 \mathrm{C}_{2} \mathrm{H}_{6} \mathrm{O} \\
& +0.12 \mathrm{C}_{2} \mathrm{H}_{4} \mathrm{O}_{2}+0.06 \mathrm{C}_{4} \mathrm{H}_{8} \mathrm{O}_{2}+0.58 \mathrm{CO}_{2}+0.36 \mathrm{H}_{2}
\end{aligned}
$$

Butanol production from glucose by C.pasteurianum:

$$
\begin{aligned}
1.00 \mathrm{C}_{6} \mathrm{H}_{12} \mathrm{O}_{6} \rightarrow & 0.54 \mathrm{C}_{4} \mathrm{H}_{10} \mathrm{O}+0.40 \mathrm{C}_{3} \mathrm{H}_{6} \mathrm{O}+0.02 \mathrm{C}_{2} \mathrm{H}_{6} \mathrm{O}+0.19 \mathrm{C}_{2} \mathrm{H}_{4} \mathrm{O}_{2} \\
& +0.06 \mathrm{C}_{4} \mathrm{H}_{8} \mathrm{O}_{2}+6.77 \mathrm{CO}_{2}+3.98 \mathrm{H}_{2}
\end{aligned}
$$

Butanol production (Jones \& Woods 1986):

$$
\begin{aligned}
1.00 \mathrm{C}_{6} \mathrm{H}_{12} \mathrm{O}_{6} \rightarrow & 0.56 \mathrm{C}_{4} \mathrm{H}_{10} \mathrm{O}+0.22 \mathrm{C}_{3} \mathrm{H}_{6} \mathrm{O}+0.07 \mathrm{C}_{2} \mathrm{H}_{6} \mathrm{O}+0.14 \mathrm{C}_{2} \mathrm{H}_{4} \mathrm{O}_{2} \\
& +0.04 \mathrm{C}_{4} \mathrm{H}_{8} \mathrm{O}_{2}+2.21 \mathrm{CO}_{2}+1.35 \mathrm{H}_{2}
\end{aligned}
$$

Ratio of 1-butanol per unit of sugar (hexose) was the highest for saccharose (0.61) and the lowest for starch (0.42) but it can be stated the results were similar as presented by Jones and Woods (1986). The only exception was case of C.pasteurianum, in which remarkable amounts of carbon dioxide and hydrogen were produced not only in acidogenesis but throughout the whole fermentation period. Other experiences with the mentioned raw materials and also possible alternation of expensive but usual cultivation medium supplements, yeast extract or yeast autolysate, with cheap waste product of milk industry, whey protein concentrate, is 
presented in Patakova et al., (2009). Detailed description of the use of sugar beet juice as fermentation substrate for biobutanol production has been published, recently (Patakova et al., 2011b).

\subsection{Influence of fermentation arrangement on ABE fermentation}

An overview of batch, fed-batch and two variants of continuous bioreactor fermentation experiments using glucose cultivation medium and the strain C.pasteurianum NRRL B-598 is presented in Table 2. Both batch and fed-batch cultivations were operated about $50 \mathrm{~h}$ and a ratio of produced solvents (B:A:E) was about 2:1:0.1 in all cases. Batch cultivations were performed in media with initial glucose concentration $40 \mathrm{~g} . \mathrm{L}^{-1}$ and if usual total solvents yields referred in literature are about 30\% (Ezeji et al., 2005; Shaheen et al., 2000) then similar solvents concentrations like those shown in Table 2 were usually obtained. Therefore, higher initial glucose concentrations (60 and 80 g.L-1) were tested in flasks cultivations, however solvents concentrations remained either at the same level (for 60 g.L-1 glucose) or they were lower (for 80 g.L.- glucose) in comparison with use of glucose concentration 40 g.L.-1 and significant portion of glucose stayed in media unconsumed what might indicate a phenomenon of substrate inhibition.

Consequently, fed-batch cultivations were employed (see Table 2) in which butanol and total $\mathrm{ABE}$ concentrations were moderately increased (about 10\%) and lag growth phase was reduced to $50 \%$ i.e. $3 \mathrm{~h}$ (data not shown). Nevertheless, yield and productivity for both 1butanol and total solvents remained almost the same as in case of batch cultivations. The reached maximal butanol concentration $\left(8.3\right.$ g. $\left.\mathrm{L}^{-1}\right)$ is probably near the highest value tolerated by the used strain and a substantial improvement in an overall amount of produced butanol could be attained only by an integration of the cultivation with some online separation step.

\begin{tabular}{|c|c|c|c|c|c|c|}
\hline cultivation & $\mathrm{B}\left(\mathrm{g} \cdot \mathrm{L}^{-1}\right)$ & $\begin{array}{c}\mathrm{ABE} \\
\left(\mathrm{g} . \mathrm{L}^{-1}\right)\end{array}$ & $\mathrm{Y}_{\mathrm{ABE} / \mathrm{S}}(\%)$ & $\mathrm{B} / \mathrm{A}$ ratio & $\mathrm{P}_{\mathrm{ABE}}\left(\mathrm{g} \cdot \mathrm{L}^{-1} \cdot \mathrm{h}^{-1}\right)$ & $\mathrm{D}\left(\mathrm{h}^{-1}\right)$ \\
\hline batch & 7.3 & 11.8 & 35 & 2.0 & 0.23 & - \\
\hline fed-batch & 8.3 & 12.3 & 23 & 2.2 & 0.25 & - \\
\hline continuous $^{\mathrm{a}}$ & 4.4 & 6.2 & 24 & 3.4 & 0.15 & 0.03 \\
\hline continuous $^{\mathrm{b}}$ & 4.0 & 5.9 & 20 & 1.8 & 0.20 & 0.07 \\
\hline
\end{tabular}

Abbreviations $\mathrm{B}, \mathrm{ABE}, \mathrm{Y}_{\mathrm{ABE} / \mathrm{S}}, \mathrm{Y}_{\mathrm{B} / \mathrm{S}}, \mathrm{P}_{\mathrm{ABE}}$ and $\mathrm{D}$ stand for butanol, total solvents amount, yield of total solvents, yield of butanol, productivity of solvents formation and dilution rate. Continuous cultivation proceeded as glucose-limited ${ }^{a}$ or glucose non-limited ${ }^{b}$ experiments; values of yield and productivity were calculated in pseudo steady state. For detailed conditions of continuous fermentations see Patakova et al., 2011a.

Table 2. Parameters of batch, fed-batch and continuous fermentations using C.pasteurianum

Surprisingly, glucose-limited fermentation experiment showed superior results in comparison with glucose non-limited fermentation (see Table 2). The only exception was solvents productivity that was higher at the expense of unused substrate. In glucose nonlimited continuous experiment, mutually adverse oscillations of butanol and glucose concentrations occurred unlike butanol concentration near constant value (pseudo steady state) achieved in glucose-limited fermentation. The glucose limitation is also believed to support long-term stability and to reduce strain degeneration (Fick et al., 1985). Fermentation courses in both cases were presented in Patakova et al., 2011a. 


\subsection{Strains comparison}

Course of fermentations carried out with C.acetobutylicum DSM 1731 and milled corn as substrate was similar to that referred for C.acetobutylicum ATCC 824 (Lee S.Y. et al., 2008) i.e. it was characterized by distinct metabolic phases, reutilization of acids during solventogenesis and development of hydrogen that peaked during acidogenesis. According to Johnson et al., (1997), C.acetobutylicum DSM 1731 showed 96\% DNA sequence similarity with C.acetobutylicum ATCC 824. The so-called acid crash i.e. the state when the fermentation finished in acidogenic step was sometimes observed from unclear reason, using this strain and milled corn as substrate (Rychtera et al., 2010). Unfortunately, intracellular level of formic acid was not determined and therefore it was not proved or disproved whether acid crash in these cases was also caused by formic acid (Wang et al., 2011).

The strain C.beijerinckii CCM 6218 should be identical with the strain C.beijerinckii ATCC 17795 according to data of Czech Collection of Microorganisms. Surprisingly, if the strain C.beijerinckii ATCC 17795 was tested for butanol production using molasses cultivation medium (Shaheen et al., 2000), both yield and maximum butanol production was low, 10\% and 6.1 g.L-1, respectively. In addition this strain together with C.pasteurianum NRRL B-598 showed different fermentation pattern in comparison with C.pasteurianum NRRL B-598 and butanol production initiation started during exponential growth phase. The strain also metabolized substrate, saccharose, faster than both other tested strains what was reflected in higher productivity of butanol.

The strain Clostridium pasteurianum NRRL B-598 used in this study differed significantly in some physiological traits from both the species characteristics published in Bergey`s Manual of Systematic Bacteriology (Rainey et al., 2009). Although strains of the species C. pasteurianum are known rather as acetic and butyric acids or hydrogen producers (Rainey et al., 2009; Heyndrickx et al., 1991), the strain C.pasteurianum NRRL B-598 was cited in US Patent No 4539293 as butanol producing when used in mixture with further acidogenic strain e.g. C.butylicum. Unfortunately precise cultivation conditions, yields, solvents concentrations and other data are not available in the mentioned patent.

\subsection{Separation of biobutanol from fermentation medium by gas stripping}

Gas stripping by nitrogen as a method potentially enabling both butanol preconcentration before final distillation and a way how to mitigate butanol toxicity during fermentation was studied separately from fermentation and stripping coefficient $\beta$, defined by equation (5) was chosen as main criterion for stripping efficiency:

$$
\beta=\left(-1 / P_{L}\right)\left(d P_{L} / d t\right)
$$

where $\mathrm{P}_{\mathrm{L}}$ is butanol concentration in a liquid phase.

Gas stripping of solvents from fermentation media is however only the first step towards isolation/concentration of products $(\mathrm{ABE})$, further steps consist in product change of state from the gas into liquid phases. There are several ways how to carry out this change of state but there are scarcely discussed. Two of them i.e. application of low temperature $\left(-4{ }^{\circ} \mathrm{C}\right.$ in condenser) and adsorption on charcoal followed by desorption by steam were tested. If low temperature was used for butanol conversion from the gas to liquid, average achieved preconcentration lay in the interval from 7 to 9 . However, when the method of freezing was used then only $60 \%$ of solvents were captured in one gas cycle (probably due to insufficiency of freezing unit capacity) while at charcoal adsorption, $90 \%$ of solvents was 
captured. This affected stripping efficiency which was lowering gradually at freezing. On the contrary, main disadvantage of charcoal use was a gain of more diluted butanol solution (preconcentration from 2 to 4 ) after its displacement from charcoal by steam. Energy balance must be done for this process but it needs measurement in pilot scale.

\begin{tabular}{|c|c|c|c|c|c|c|c|c|}
\hline & \multicolumn{4}{|c|}{ Model solution ABE } & \multicolumn{4}{c|}{ Medium after fermentation } \\
\cline { 2 - 9 } & $\begin{array}{c}\text { Initial } \\
\text { conc. } \\
\left(\mathrm{g} . \mathrm{L}^{-1}\right)\end{array}$ & $\begin{array}{c}\text { Final conc. } \\
\left(\mathrm{g} . \mathrm{L}^{-1}\right)\end{array}$ & $\begin{array}{c}\text { Mean rate } \\
\text { of stripping } \\
\left(\mathrm{g} . \mathrm{L}^{-1} \cdot \mathrm{h}^{-1}\right) \\
(\text { for } 24 \mathrm{~h})\end{array}$ & $\begin{array}{c}\text { Stripping } \\
\text { coefficient } \\
\left(\mathrm{h}^{-1}\right) \\
(\text { for } 24 \mathrm{~h})\end{array}$ & $\begin{array}{c}\text { Initial } \\
\text { conc. } \\
\left(\mathrm{g} . \mathrm{L}^{-1}\right)\end{array}$ & $\begin{array}{c}\text { Final } \\
\text { conc. } \\
\left(\mathrm{g} . \mathrm{L}^{-1}\right)\end{array}$ & $\begin{array}{c}\text { Mean rate } \\
\text { of stripping } \\
\left(\mathrm{g} . \mathrm{L}^{-1} \cdot \mathrm{h}^{-1}\right) \\
(\text { for } 24 \mathrm{~h})\end{array}$ & $\begin{array}{c}\text { Stripping } \\
\text { coefficient } \\
\left(\mathrm{h}^{-1}\right) \\
(\text { for } 24 \mathrm{~h})\end{array}$ \\
\hline A & 3.9 & 2.6 & 0.05 & 0.017 & 4.8 & 2.6 & 0.09 & 0.025 \\
\hline B & 9.2 & 3.2 & 0.25 & 0.044 & 10.2 & 2.9 & 0.30 & 0.052 \\
\hline E & 1.4 & 0.7 & 0.03 & 0.029 & 0.7 & 0.5 & NA & NA \\
\hline
\end{tabular}

The profound influence of solution composition on stripping efficiency is shown in Table 3, where comparison of model (water) solution of solvents with medium after fermentation is provided. In this case, the stripping was carried out directly in the bioreactor (liquid volume $3 \mathrm{~L}$ ) using aeration ring as nitrogen distributor (flow rate $2 \mathrm{VVM}$ ). Schemes of stripping arrangements are provided in (Fribert et al., 2010).

Table 3. Comparison of butanol stripping from model solution and cultivation medium after fermentation

Nevertheless, if summarized it can be stated that the mean rate of stripping for butanol and butanol preconcentrations achieved after application of freezing corresponded with already published values (Ezeji et al., 2003; Ezeji et al., 2005; Qureshi \& Blaschek, 2001b). The mean butanol stripping rate exceeded the butanol productivity what indicated a potential successful integration of gas stripping with fermentation into one process.

\section{The use of biobutanol in road transport}

\subsection{Perspectives of biobutanol use in road transport}

The preferred use of biobutanol is the production of motor fuels for spark ignition engines by mixing with conventional gasoline; therefore biobutanol could become an option to bioethanol due to better potential in terms of its physico-chemical properties. Biobutanol concentration in fuel can reach up to $30 \% \mathrm{v} / \mathrm{v}$ without the need for engine modification. Since the butanol fuel contains oxygen atoms, the stoichiometric air/fuel ratio is smaller than for gasoline and more fuel could be injected to increase the engine power for the same amount of air induced. The oxygen content is supposed to improve combustion, therefore lower $\mathrm{CO}$ and $\mathrm{HC}$ emissions can be expected. Biobutanol and its mixtures can be used directly in the current gasoline supply system, such as transportation tanks and re-fuelling infrastructure. Biobutanol can be blended with gasoline without additional large-scale supply infrastructure, which is a big benefit as opposed to the bioethanol use. Finally biobutanol is non-poisonous and non-corrosive and it is easily biodegradable and does not cause risk of soil and water pollution.

\subsection{Physico-chemical properties of biobutanol-gasoline blends}

If compared to ethanol, biobutanol exhibits important advantages upon blending with gasoline. The mixtures have better phase stability in presence of water, low-temperature 
properties, oxidation stability during long-term storage, distillation characteristics and volatility with respect to possible air pollution.

The overview of the selected properties of butanol as compared to bioethanol and automotive gasoline meeting requirements of EN 228 is given in Table 4 .

\begin{tabular}{|l|c|c|c|}
\hline Parameter & Bioethanol & Biobutanol & Gasoline 95 \\
\hline Boiling Point $\left({ }^{\circ} \mathrm{C}\right)$ & 78.3 & 117.7 & $30-215$ \\
Density $\left(\mathrm{kg} \cdot \mathrm{m}^{-3}\right)$ & 794 & 809 & $720-750$ \\
Kinematic Viscosity $\left(\mathrm{mm}^{2} . \mathrm{s}^{-1}\right)$ & 1.5 & 3.6 & $0.4-0.8$ \\
Lower Heating Value $\left(\mathrm{MJ} \cdot \mathrm{kg}^{-1}\right)$ & 28.9 & 33.1 & 44.4 \\
Heat of vaporisation $\left(\mathrm{MJ} . \mathrm{kg}^{-1}\right)$ & 0.92 & 0.71 & 0.32 \\
Research Octane Number RON & $106-130$ & 94 & 95 \\
Motor Octane Number MON & $89-103$ & 80 & 85 \\
Reid Vapour Pressure (kPa) & 17 & 2.3 & $45-90$ \\
Stoichiometric air/fuel ratio & 9 & 11.1 & 14.8 \\
\hline Oxygen Content $(\% \mathrm{w} / \mathrm{w})$ & 34.7 & 21.6 & max 2.7 \\
\hline
\end{tabular}

Table 4. Physico-chemical properties of alcohols and automotive gasoline (Wolf, 2007)

Due to the fact that oxygen content in biobutanol is lower than in ethanol, biobutanol can be added to the gasoline in higher concentrations with respect to EN 228 limit for the oxygen content in gasoline. Higher biobutanol content in gasoline does not require engine modification. The heating value (energy density) of biobutanol is close to that of gasoline, which has a positive effect on the fuel consumption.

Biobutanol has a slightly higher density compared to gasoline but the increase in density of biobutanol/gasoline mixtures is so small that it does not cause problems with fulfilling limits for automotive gasoline containing up to $30 \% \mathrm{v} / \mathrm{v}$ biobutanol. Viscosity of biobutanol is significantly higher compared to the gasoline, which may affect engine fuel injection system at lower temperatures due to higher resistance to flow. However, this impact could be negligible for the blends with gasoline containing up to $30 \% \mathrm{v} / \mathrm{v}$ biobutanol.

\subsubsection{Volatility of biobutanol-gasoline blends}

The vapour pressure of biobutanol and bioethanol is very low compared to gasoline. A disadvantage of the bioethanol use is a formation of volatile azeotropic mixtures of ethanol and hydrocarbons present in the gasoline which causes the increase in the vapour pressure of gasoline in the range of $6-8 \mathrm{kPa}$ (Mužíková et al., 2009). The formation of azeotropes occurs in the concentration up to $10 \% \mathrm{v} / \mathrm{v}$ of biobutanol in gasoline but the highest increase in the vapour pressure is as low as $0.5 \mathrm{kPa}$ at $5 \% \mathrm{v} / \mathrm{v}$ of biobutanol in gasoline. At higher biobutanol concentrations, another volatile and/or oxygen compound has to be added to compensate vapour pressure decrease and to keep good engine startability. The formation of azeotropes is also associated with decrease of the boiling points of the blends. While the addition of bioethanol influences negatively the distillation curve profile, biobutanol has minor effect on the distillation curve.

Because of the use of different gasolines in several European Union countries, the mixing of different oxygen compounds in the vehicle tank can occur, causing the simultaneous 
presence of ethers like MTBE and ETBE and other alcohols, especially ethanol, in combination with biobutanol in the gasoline. Ethers do not cause problems since their properties are close to hydrocarbons. They influence the vapour pressure of the butanolgasoline blend proportionally according to the initial vapour pressure of pure components. On the contrary, bioethanol forms azeotropes, which can unpredictably change the vapour pressure of the mixture. The increase of vapour pressure depends on the final ethanol concentration in the mixture.

Biobutanol has significantly higher heat of vaporization than gasoline, which reduces the temperature of the air/fuel mixture and results in higher engine volumetric efficiency. At the same time it leads to lower compression temperature and longer ignition delay, which in turn may decrease the engine performance. The low vapour pressure and higher heat of vaporization is experienced to have a negative effect on the startability and cold start engine performance because of difficult fuel vaporization at low ambient temperatures (Xiaolong et al., 2009).

\subsubsection{Phase stability in the presence of water}

The water - fuel miscibility is very important factor for distribution of fuel blends. The content of small amounts of free water in the fuel is connected with the risk of corrosion problems, whereas larger amounts of water can impair fuel supply to the engine. Hydrocarbons in gasoline are very slightly miscible with water as opposed to alcohols. The solubility of water in petroleum gasoline is only $100 \mathrm{mg} \cdot \mathrm{kg}^{-1}$, while bioethanol is completely miscible with water and solubility of water in biobutanol is $19.7 \% \mathrm{w} / \mathrm{w}$. Bioethanol is very hygroscopic and its blends with gasoline are partially miscible with water depending on temperature and the ethanol concentration in the blend. Phase separation of water with bioethanol can occur at lower temperatures, which causes formation of the heterogeneous system composed of the hydrocarbon phase and water-ethanol phase. This fact is the reason why the bioethanolgasoline blends cannot be distributed via common pipelines but only separately using tankers. Contrary to bioethanol, the ability of biobutanol to absorb significant amount of water is very low (Peng et al., 1996). Biobutanol has high affinity to hydrocarbons and the risk of potential phase separation is therefore minimized. Moreover, biobutanol remains in the hydrocarbon phase if the phase separation occurs. Biobutanol is not hygroscopic that is an important factor for the long-term storage of fuels. Accordingly, high stability of gasoline-biobutanol mixtures in the presence of water comparing with bioethanol was reported.

Ethers MTBE and/or ETBE can be added to the gasoline on purpose for increasing the octane number and oxygen content or they can be accidentally mixed in the fuel tank due to another type of gasoline fuelling. The presence of MTBE and ETBE slightly increases the miscibility of butanol-gasoline blend with water and decreases the temperature of the phase separation. Ethanol has the same behaviour, nevertheless due to the bioethanol ability to absorb humidity its presence in the blends is rather unfavourable.

\subsubsection{Material compatibility of biobutanol and its mixtures}

Biobutanol is not as aggressive as the bioethanol with regard to the engine construction materials, sealants, and plastics. The fuel with $20 \% \mathrm{v} / \mathrm{v}$ of biobutanol has similar properties to the hydrocarbons in terms of swelling of polymers (Wolf, 2007).

The oxidation stability of biobutanol-gasoline blends may be compromised by potential impurities from biobutanol production (acetic and butyric acid, acetaldehyde and lower alcohols). The impurities in concentrations of $0.1 \% \mathrm{v} / \mathrm{v}$ in $10 \% \mathrm{v} / \mathrm{v}$ biobutanol-gasoline blends (which corresponds to $1 \%$ of impurities in biobutanol) can decrease the fuel 
oxidation stability by about $15 \%$, therefore the purification with regard to the removal of fermentation by-products is very important step in biobutanol production.

The high boiling point of butanol may negatively influence its evaporation from engine oil after oil contamination caused by frequent cold starts. This phenomenon can occur especially at low ambient temperatures, when the fuel leaks into the engine oil through piston rings. In a normal engine operation biobutanol evaporates after the engine warm up and the motor oil additives are re-solved. However, the solubility of oil additives may be at risk in case of frequent cold starts and short routes in cold winter conditions.

\subsection{Emission characteristics of butanol/gasoline blends in spark ignition engines}

Besides the renewability of raw materials used for their production, alcohol fuels are reported to be advantageous over petroleum derived ones thanks to their better environmental characteristics. The oxygen contained in alcohol molecules is supposed to affect combustion process and cause soot and particulate reduction; some studies show that there is the potential for reduction of $\mathrm{NO}_{x}$ emissions. While there was much information collected about the use and combustion behaviour of lower-molecular weight alcohols, such as methanol and ethanol, substantially less effort was yet put to the research of the properties of butanol (especially n-butanol as a product of fermentation during $\mathrm{ABE}$ process) upon their use in internal combustion engines.

For the evaluation of emission characteristics, it is very important to study combustion processes at different air/fuel ratio and thermodynamic conditions. The combustion of neat butanol as well as its mixtures with other fuels or chemicals was studied (Agathou \& Kyritis, 2011; Broustail et al., 2011; Dagaut \& Togbé, 2008; Sarathy et al., 2009) to obtain combustion velocities and kinetic data for modelling processes of butanol oxidation at the conditions of engine cylinder. However, it must be noted that real-world emissions level is affected by the interaction between fuel itself and the engine used, mainly its fuel injection system and engine control unit together with emission control systems - catalytic converters, particulate filters, exhaust recirculation etc.

Although butanol properties (boiling point, viscosity, octane number) predetermine it for the use in spark ignition engines as a partial substitute for conventional gasoline, a number of studies were carried out using butanol/diesel fuel mixtures in compression ignition engines. The addition of butanol (or other alcohols) significantly increases volatility and decrease lubricity of diesel fuel, which requires additional measurements for their use in today's diesel engines. Yao (Yao et al., 2010) studied emission characteristics of CI engine using diesel fuel containing $0 \%$ to $15 \% \mathrm{v} / \mathrm{v}$ n-butanol. By varying exhaust gas recirculation rates, they kept $\mathrm{NO}_{x}$ emissions constant, while $\mathrm{CO}$ and $\mathrm{PM}$ (particulate matter) emissions significantly decreased with the concentration of n-butanol in the fuel. Rakopoulos et al. (Rakopoulos et al., 2010a) compared conventional diesel fuel, diesel fuel with $30 \%$ biodiesel (FAME), and biodiesel with $25 \%$ n-butanol in turbo-charged CI truck engine; the experiments were focused on transient regimes causing temporary increase of pollutant emissions. Both FAME and butanol helped to improve the particulate emissions in the transient engine regimes, but in both cases the emissions of $\mathrm{NO}_{\mathrm{x}}$ increased. In stationary regimes at different engine speed and load, the authors (Rakopoulos et al., 2010b) determined emissions of all regulated pollutants. In all cases, the positive effect of butanol in diesel fuel was found on the emissions of particulates, $\mathrm{NO}_{\mathrm{x}}$, and carbon dioxide, whereas hydrocarbon emissions slightly increased.

Much greater potential and possibility of utilization without necessity to solve technical problems has butanol used as a partial substitute of motor gasoline. The total miscibility 
with hydrocarbons, boiling point, flash point and other properties allow mixing butanol with gasoline in wide range of concentrations and combustion in common spark ignition engines. In comparison to other alcohols in the range of $C_{1}$ to $C_{5}$ mixed to gasoline in concentrations matching fuel oxygen content, butanol does not differ significantly in its effect on the emissions of regulated pollutants (Yacoub et al., 1998). The emissions of total hydrocarbons decrease, while significant increase takes place in the emissions of aldehydes, whose main constituent was formaldehyde.

One of the substantial drawbacks connected with the use of alcohols in SI engines is the problem of cold starts especially in winter conditions. Difficulties caused mainly by high heat of vaporization have to be eliminated by greater enrichment of air/fuel mixture in the period in which the engine heats up. This, on the other hand, can bring an increase in emissions of unburned or partially burned fuel due to near zero efficiency of catalytic converter in the early period after engine start. Irimescu (2010) modelled the situation for gasoline/butanol mixtures at different ambient temperatures and successfully verified the results with those obtained in experiments with a port injection engine.

The effect of butanol (or other alcohols) use in spark ignition engines depends also on the technique of fuel injection before its ignition in engine cylinder. Conventional way to prepare air/fuel mixture is the injection of fuel into the engine intake manifold, where it evaporates and the mixture is drawn to the cylinder in the suction cycle. Some engine manufacturers offer engines equipped with direct injection of fuel into the cylinder. Such engines allow the use of advanced techniques of emission control, such as lean (stratified) mixture combustion connected with the use of sequential injection. The direct injection engine was used by Cooney (Cooney et al., 2006), who investigated the effect of ethanol and butanol in blends with gasoline used in a series of engine tests conducted at varied loads. They reported the increase in engine efficiency at higher engine loads by a $4 \%$ with either $85 \%$ n-butanol or $85 \%$ ethanol. The efficiency is reported to be affected by lower octane number of n-butanol, even though knock combustion was not observed, and, on the other hand, by the higher flame speed of alcohols. Faster combustion can increase the efficiency if combustion timing was adjusted, while lower octane number should decrease it.

In contrast to modern engines of current passenger cars, there are still applications where carburetted engines or engines with open-loop control of fuel injection are used, without the ability to compensate for air-fuel ratio of specific fuels. In such cases, butanol blends result in approximately 50\% enleanment connected with oxygen content in fuel, compared to ethanol. The authors evaluated the effect of the use of butanol-gasoline mixtures on pollutants emission of four different passenger cars equipped with spark ignition engines from older Euro 2 vehicle to modern multipoint injection turbocharged one. As a baseline, unleaded gasoline with addition of $4 \%$ ethanol was used. Mixtures containing butanol were prepared by addition of $10 \%, 20 \%$, and $30 \%$ pure synthetic n-butanol to the same gasoline. The properties of the mixtures were modified with small amounts of isooctane, toluene, and petroleum ether to keep their octane number and vapour pressure, which deteriorated by the addition of butanol. Four test vehicles manufactured by Skoda were used with different engine displacement, power, and technology level (see Table 5).

The emission tests were performed on a vehicle dynamometer according to ECE 83 emission test with the determination of $\mathrm{CO}, \mathrm{HC}$, and $\mathrm{NO}_{x}$ emissions during two driving cycles. In addition to the measurement of regulated emissions, samples were taken during both phases of ECE 83 test for determination of individual hydrocarbons and aldehydes. Basic 
engine parameters were monitored during the tests using an engine diagnostic unit to detect possible abnormal operation states of engine control unit.

\begin{tabular}{|c|c|c|c|c|}
\hline $\begin{array}{c}\text { Vehicle } \\
\text { type }\end{array}$ & $\begin{array}{c}\text { Year of } \\
\text { manufacture }\end{array}$ & $\begin{array}{c}\text { Engine displacement } \\
{\left[\mathrm{cm}^{3}\right]}\end{array}$ & $\begin{array}{c}\text { Maximum power } \\
{[\mathrm{kW}]}\end{array}$ & Engine characteristics \\
\hline $\begin{array}{c}\text { Felicia } \\
\text { Euro 2 }\end{array}$ & 1999 & 1289 & 50 & $\begin{array}{c}\text { Multi-point injection, } \\
\text { four-cylinder }\end{array}$ \\
\hline $\begin{array}{c}\text { Fabia } \\
\text { Euro4 }\end{array}$ & 2004 & 1198 & 47 & $\begin{array}{c}\text { Multi-point injection, } \\
\text { three-cylinder }\end{array}$ \\
\hline $\begin{array}{c}\text { Octavia } \\
\text { Euro4 }\end{array}$ & 2004 & 1781 & 110 & $\begin{array}{c}\text { Multi-point injection, } \\
\text { 20V, } \\
\text { five-cylinder, } \\
\text { turbocharged }\end{array}$ \\
\hline
\end{tabular}

Table 5. Characteristics of vehicles used for emission tests

The addition of butanol to the fuels used caused only little change in regulated emissions (Fig. 6) measured in ECE 83 test. Although more significant changes were found in emission levels determined in individual ECE 83 test phases, with regard to regulated pollutants, total values show only the increase in $\mathrm{NO}_{x}$ emissions for all three vehicles. As expected, the use of butanol caused also small increase in emissions of aldehydes, whose main constituent was formaldehyde.
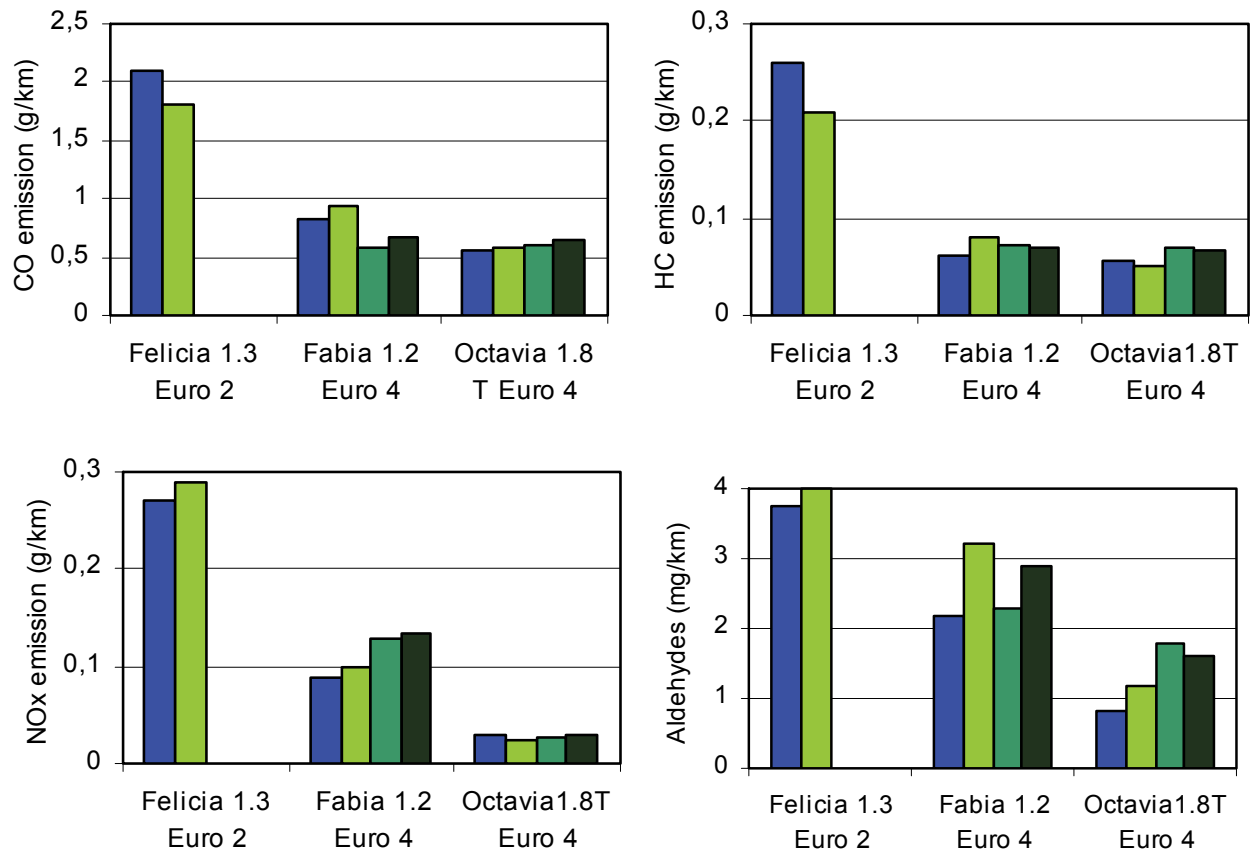

Reference $\square 10 \%$ Biobutanol $\square 20 \%$ Biobutanol $\square 30 \%$ Biobutanol

Fig. 6. Effect of butanol in gasoline fuel on emissions of regulated pollutants $\left(\mathrm{CO}, \mathrm{HC}, \mathrm{NO}_{\mathrm{x}}\right)$ and aldehydes in ECE 83.03 emission test 


\section{Conclusion}

The significance of the presented fermentation data lies in several fields:

- methodologically - fluorescence staining and flow cytometry proved to be very useful tools for nearly on-line evaluation of physiological state of clostridial population during the fermentation. Both method of discrimination of acidogenic/solventogenic status of individual cells based on fluorescence alternative to Gram staining and vitality staining by bisoxonol were never applied on bacteria of the genus Clostridium.

- the greatest attention was concentrated on the strain C.pasteurianum NRRL B-598 which was never studied before in such detail. The comparison of three types of fermentation arrangements, batch, fed-batch and continuous represents the unique set of data not usually available for the tested butanol producers. As the strain had somewhat distinct physiology from type C.pasteurianum strains and flow cytometry analysis displayed very short acidogenic metabolic phase and presumable overlapping of acidogenic and solventogenic phases, the strain itself and its behaviour is worth further investigation. Moreover, the strain can also be regarded the very promising hydrogen producer

- the best fermentation parameters, yield of ABE 37\% and ABE productivity 0.40 g.L-1.h.h were achieved using sugar beet juice as the feedstock and C.beijerinckii CCM 6182 as the microbial agent. In Europe and especially in the Czech Republic, the sugar beet has a potential to become significant source of sugar utilizable for non-food purposes. The abilities and the fermentation characteristics of the strain C.beijerinckii CCM 6182 (and neither its analog C.beijerinckii ATCC 17795) has not been studied intensively although the strain behaved like C.pasteurianum NRRL B-598 i.e. favourable butanol production kinetics consisting in onset of butanol formation during exponential growth phase was its typical feature.

- the preliminary experiments dealing with gas stripping as potential concentration and/or separation method for solvents from the fermented media confirmed feasibility of this solution under certain assumptions. The gas stripping must not affect adversely the fermentation and cost of the solvents transition from the gas into liquid phases must be minimized. However further ideally pilot experiments are necessary for full evaluation of gas stripping role in the butanol production.

With reference to the use of biobutanol as a fuel for transportation purposes, it can be concluded:

- in comparison with other bio-components used for blending automobile fuels, especially bioethanol, biobutanol exhibits very attractive properties - high energy content, low water solubility, total miscibility with gasoline hydrocarbons, and appropriate boiling point and vapour pressure

- the use of gasoline containing high concentrations (10\% to $30 \% \mathrm{v} / \mathrm{v})$ of butanol did not negatively affect operational parameters of common spark ignition engines used in passenger cars representing current European vehicle fleet. Only slightly increased emissions of $\mathrm{NO}_{x}$ emissions and production of aldehydes was found out during standard ECE 83 emission tests

\section{Acknowledgement}

This research could be performed thanks to financial support of projects No. QH81323/2008 of the Ministry of Agriculture of the Czech Republic, TIP No. FR-TI1/218 of the Ministry of 
Industry and Trade of the Czech Republic, No. MSM6046137305 and No. MSM 6046137304 of the Ministry of Education, Youth and Sport of the Czech Republic.

\section{References}

Agathou, M.S. \& and Kyritis, D.C. (2011) An experimental comparison of non-premixed biobutanol flames with the corresponding flames of ethanol and methane, Fuel, Vol. 90, No. 1, pp. 255-262, ISSN 0016-2361

Bahl, H.; Andersch, W. \& Gottschalk, G. (1982) Continuous production of acetone and butanol by Clostridium acetobutylicum in two stage phosphate limited chemostat, European Journal of Applied Microbiology and Biotechnology, Vol.15, No.4, pp. 201-205, ISSN 0171-1741

Beesch, S.C. (1953) Acetone-butanol fermentation of starches, Applied Microbiology, Vol. 1, No. 2, pp. 85-96, ISSN 0099-2240

Beveridge, T.J. (1990) Mechanism of Gram variability in select bacteria, Journal of Bacteriology, Vol. 172, No. 3, pp. 1609-1620, ISSN 0021-9193

Broustail, G.; Seers, P.; Halter, F.; Moreac, G. \& Mounaim-Rousselle, C. (2011) Experimental determination of laminar burning velocity for butanol and ethanol iso-octane blends, Fuel, Vol. 90, No. 1, pp. 1-6, ISSN 0016-2361

Chiao, J-S. \& Sun, Z-H. (2007) History of acetone-butanol-ethanol fermentation industry in China: Development of continuous production technology, Journal of Molecular Microbiology and Biotechnology, Vol. 13, No. 1-3, pp. 12-14, ISSN 1464-1801

Clarke, K.G.; Hansford, G.S. \& Jones, D.T. (1988) Nature and significance of oscillatory behavior during solvent production by Clostridium acetobutylicum in continuous culture, Biotechnology \& Bioengineering, Vol. 32, No. 4, pp. 538-544, ISSN 0006-3592

Cooney, C.; Wallner, T; McConell, C.; Gillen, J.C.; Abell, C. \& Miers, C.A. (2006) Effect of blending gasoline with ethanol and butanol on engine efficiency and emissions using a direct-injection, spark-ignition engine, In: Proceedings of the ASME internal combustion engine division 2009 spring technical conference ICES2009-76155, Milwaukee, Wisconsin, USA, 2006

Cornillot, E.; Nair, R.; Papoutsakis, E.T. \& Soucaille, P. (1997) The genes for butanol and acetone formation in Clostridium acetobutylicum ATCC 824 reside on a large plasmid whose loss leads to degeneration of the strain, Journal of Bacteriology, Vol. 179, No. 17, pp. 5442-5447, ISSN 0021-9193

Dagaut, P. \& Togbé, C. (2008) Oxidation kinetics of butanol-gasoline surrogate mixtures in a jet-stirred reactor: Experimental and modeling study, Fuel, Vol. 87, No. 15-16, pp. 3313-3321, ISSN 0016-2361

Dyr, J. \& Protiva, J. (1958) Formation of neutral solvents in continuous fermentation by means of Clostridium acetobutylicum. In: Continuous Cultivation of Microorganisms A symposium, Málek, I., pp. 210-226, Publishing House of the Czechoslovak Academy of Sciences, Prague 1958.

Ezeji, T.C.; Qureshi, N. \& Blaschek, H.P (2003) Production of acetone, butanol and ethanol by Clostridium beijerinckii BA101 and in situ recovery by gas stripping, World Journal of Microbiology and Biotechnology, Vol. 19, No. 6, pp. 595-603., ISSN 0959-3993

Ezeji, T.C.; Qureshi, N. \& Blaschek, H.P. (2005) Industrially relevant fermentations. In Handbook on Clostridia, Dürre, P., pp. 797-812, CRC Press, ISBN 0-8493-1618-9, Boca Raton.

Fick, M.; Pierrot, P. \& Engasser, J.M. (1985) Optimal conditions for long-term stability of acetone-butanol production by continuous cultures of Clostridium acetobutylicum, Biotechnology Letters, Vol. 7, No. 7, pp. 503-508, ISSN 0141-5492 
Fribert, P.; Patakova, P.; Jahodova, L.; Lipovsky, J.; Linhova, M.; Rychtera, M. \& Melzoch, K. (2010) Recovery of acetone, butanol and ethanol from fermentation broth by gas stripping, Proceedings of 19th International Congress of Chemical and Process Engineering, ISBN 978-80-02-02210-7, Prague, Czech Republic, September 2010

Gheslaghi, R.; Scharer, J.M.; Moo-Young, M. \& Chou, C.P. (2009) Metabolic pathway of clostridia for producing butanol, Biotechnology Advances, Vol. 27, No. 6, pp. 764-781, ISSN 0734-9750

Hanno, R.; Qureshi, N.; Cotta, M. \& Largus A. (2010) Mixed community bioreactors to convert lignocellulosic feedstock into the liquid biofuel butanol, February 27, 2011, Available from:http://www.ars.usda.gov/research/publications/publications.htm?seq_no_11 $5=248960$

Hartmanis, M.G.; Ahlman, H. \& Gatenbeck, S. (1986) Stability of solvent formation in Clostridium acetobutylicum, Applied Microbiology and Biotechnology, Vol. 23, No. 5, pp. 369-371, ISSN 0175-7598

Heyndrickx, M.; De Vos, P. \& De Ley, J. (1991) Fermentation characteristics of Clostridium pasteurianum LMG 3285 grown on glucose and mannitol, Journal of Applied Bacteriology, Vol. 70, No. 1, pp. 52-58, ISSN 1364-5072

Irimescu, A. (2010) Study of cold start air-fuel mixture parameters for spark ignition engines fueled with gasoline-isobutanol blends, International Communications in Heat and Mass Transfer, Vol. 37, No. 9, pp. 1203-1207, ISSN 0735-1933

Jepras, R.I.; Carter, J.; Pearson, S.C.; Paul, F.E. \& Wilkinson, M.J. (1995) Development of a robust flow cytometric assay for determining numbers of viable bacteria, Applied and Environmental Microbiology, Vol. 61, No. 7, pp. 2696-2701, ISSN 0099-2240

Johnson, J.L., Toth, J., Santiwatanakul, S. \& Chen, J.-S. (1997) Culture of Clostridium acetobutylicum from various collections comprise Clostridium acetobutylicum, Clostridium beijerinckii and two other distinct types based on DNA-DNA reassociation, International Journal of Systematic Bacteriology, Vol. 47, No. 2, pp. 420-424, ISSN 0020-7713

Jones, D.T.\& Woods, D.R. (1986). Acetone-butanol fermentation revisited, Microbiological Rewievs, Vol. 50, No. 4, pp. 484-524, ISSN 0146-0749

Jones, D.T.; Shirley, M.; Wu, X. \& Keis, S. (2000) Bacteriophage infections in the industrial acetone butanol (AB) fermentation process, Journal of Molecular Microbiology and Biotechnology, Vol. 2, No. 1, pp. 21-26, ISSN 1464-1801

Jones, S. W.; Paredes, C. J.; Tracy, B.; Cheng, N.; Sillers, R.; Sanger, R. S.\& Papoutsakis, E. T. (2008) The transcriptional program underlying the physiology of clostridial sporulation, Genome Biology, Vol. 9, No. 7, pp. R114-R114.21, ISSN 1465-6914

Kashket, E.R. \& Cao, Z.-Y. (1995) Clostridial strain degeneration, FEMS Microbiology Reviews, Vol. 17, No. 3, pp. 307-315, ISSN 0168-6445

Kosaka, T.; Nakayama, S.; Nakaya, K.; Yoshino, S. \& Furukawa, S. (2007) Characterization of the sol operon in butanol-hyperproducing Clostridium saccharoperbutylacetonicum strain N1-4 and its degeneration mechanism, Bioscience, Biotechnology and Biochemistry, Vol. 71, No. 1, pp. 58-68, ISSN 0916-8451

Largier, S.T.; Long, S.; Santangelo, J.D.; Jones, D.T. \& Woods, D.R. (1985) Immobilized Clostridium acetobutylicum P262 mutants for solvent production, Applied and Environmental Microbiology, Vol. 50, No. 2, pp. 477-481, ISSN 0099-2240

Lee, S.M.; Cho, M.O.; Park, C.H.; Chung, Y-C.; Kim, J.H.; Sang, B-I. \& Um, Y. (2008) Continuous butanol production using suspended and immobilized Clostridium 
beijerinckii NCIMB 8052 with supplementary butyrate, Energy \& Fuels, Vol. 22, No. 5, pp. 3459-3464, ISSN 0887-0624

Lee, S.Y.; Park, J.H.; Jang, S.H.; Nielsen, L.K.; Kim, J. \& Jung, K.S. (2008) Fermentative butanol production by clostridia, Biotechnology and Bioengineering, Vol. 101, No. 2, pp. 209-228, ISSN 0006-3592

Linhova, M.; Patakova, P.; Lipovsky, J.; Fribert, P.; Paulova, L.; Rychtera, M. \& Melzoch, K. (2010a) Development of flow cytometry technique for detection of thinning of peptidoglycan layer as a result of solvent production by Clostridium pasteurianum, Folia Microbiologica, Vol. 55, No. 4, pp. 340-344, ISSN 1874-9356

Linhova, M.; Branska, B.; Patakova, P.; Lipovsky, J.; Fribert, P.; Rychtera, M. \& Melzoch, K. (2010b) Viability determination by flow cytometry during ABE fermentation, Proceedings of 19th International Congress of Chemical and Process Engineering, ISBN 97880-02-02210-7, Prague, Czech Republic, September 2010

Lipovsky, J.; Patakova, P.; Rychtera, M.; Cizkova, H. \& Melzoch, K. (2009) Prospects of butanol production from starch and cellulose materials, Chemicke Listy, Vol. 103, No. 6, pp. 479-483, ISSN 1213-7103

Lopez-Contreras, A.; Gabor, K.; Martens, A A.; Renckens, B. A. M.; Claassen, P. A. M.; van der Oost, J. \& de Vos, W. M. (2004) Substrate induced production and secretion of cellulases by Clostridium acetobutylicum, Applied and Environmental Microbiology, Vol. 70, No. 9, pp. 5238-43, ISSN 0099-2240

Maddox, I.S.; Steiner, E.; Hirsch, S.; Wessner, S.; Gutierrez, N.A. ; Gapes, J.R. \& Schuster, K.C. (2000) The cause of "acid crash" and "acidogenic fermentations" during the batch acetone-butanol-ethanol (ABE-) fermentation process, Journal of Molecular Microbiology and Biotechnology, Vol. 2, No. 1, pp. 95-100, ISSN 1464-1801

Mužíková, Z.; Pospíšil, M. \& Sebor, G. (2009) Volatility and phase stability of petrol blends with ethanol, Fuel, Vol.88, No.8, pp. 1351-1356, ISSN: 0016-2361

Napoli, F.; Olivieri, G.; Russo, M.E.; Marzocchella, A. \& Salatino, P. (2010) Butanol production by Clostridium acetobutylicum in a continuous packed bed bioreactor, Journal of Industrial Microbiology and Biotechnology, Vol. 37, No. 6, pp. 603-608, ISSN 1367-5435

Ni, Y. \& Sun, Z. (2009) Recent progress on industrial fermentative production of acetonebutanol-ethanol by Clostridium acetobutylicum in China, Applied Microbiology and Biotechnology, Vol. 83, No. 3, pp. 415-423, ISSN 0175-7598

Novo, D.; Perlmutter, N.G.; Hunt, R.H. \& Shapiro, H.M. (1999) Accurate flow cytometric membrane potential measurement in bacteria using diethyloxacarbocyanine and a ratiometric technique, Cytometry, Vol. 5, No. 1, pp. 55-63, ISSN 1552-4922

Oudshoorn, A.; Van der Wielen, L.A.M. \& Straathof, A.J.J. (2009) Assessment of options for selective 1-butanol recovery from aqueous solution, Industrial $\&$ Engineering Chemical Research, Vol. 48, No. 15, pp. 7325-7336, ISSN 0888-5885

Patakova, P.; Lipovsky, J.; Cizkova, H.; Fortova, J.; Rychtera, M. \& Melzoch, K. (2009) Exploitation of food feedstock and waste for production of biobutanol. Czech Journal of Food Sciences, Vol. 27, No. 4, pp. 276-283, ISSN 1212-1800

Patakova, P.; Lipovsky, J.; Paulova, L.; Linhova, M.; Fribert, P.; Rychtera, M. \& Melzoch, K. (2011a) Continuous production of butanol by bacteria of genus Clostridium, Journal of Chemistry and Chemical Engineering, Vol. 5, No. 2, pp. 124-131, ISSN 1934-7375

Patakova, P.; Toure,S.S.M.; Simacek, P.; Cizkova, H.; Lipovsky, J.; Linhova, M.; Fribert, P., Rychtera, M. \& Melzoch, K. (2011b) Exploitation of sugar beet for biobutanol production, Czech Sugar and Sugar Beet Journal, Vol. 127, No. 2, pp. 46-49, ISSN 12103306 
Peng, Ch.; Lewis, C.K.; Stein, F.P. (1996) Water Solubilities in Blends of Gasoline and Oxygenates, Fluid Phase Equilibria, Vol.116 (1996), pp. 437-444, ISSN: 0016-2361

Pierrot, P.; Fick, M. \& Engasser, J.M. (1986) Continuous acetone-butanol fermentation with high productivity by cell ultrafiltration and recycling, Biotechnology Letters, Vol. 8, No. 4, pp. 253-256, ISSN 0141-5492

Qureshi, N. \& Blaschek, H.P. (2001a) Recent advances in ABE fermentation: hyper-butanol producing Clostridium beijerinckii BA101, Journal of Industrial Microbiology and Biotechnology, Vol. 27, No. 5, pp. 287-291., ISSN 1367-5435

Qureshi, N. \& Blaschek, H.P. (2001b) Recovery of butanol from fermentation broth by gas stripping, Renewable Energy, Vol. 22, No. 4, pp. 557-564, ISSN 0960-1481

Rainey, F.A.; Hollen, B.J. \& Small, A. (2009) Genus I. Clostridium Prazmowski 1880, 23AL. In Bergey's manual of Systematic Bacteriology, The Firmicutes, Second Edition, Volume Three, De Vos, P.; Garrity, G.M.; Jones, D.; Krieg, N.R.; Ludwig, W.; Rainey, F.A.; Schleifer, K.H. \& Whitman, W.B, pp. 738-828, Springer, ISBN 978-0-387-95041-9, New York.

Rakopoulos, C.D.; Dimaratos, A.M.; Giakoumis, E.G. \& Rakopoulos D.C. (2010a) Investigating the emissions during acceleration of a turbocharged diesel engine operating with biodiesel or n-butanol diesel fuel blends, Energy, Volume 35, No. 12, pp. 5173-5184, ISSN 0360-5442

Rakopoulos, D.C.; Rakopoulos, C.D.; Hountalas, D.T.; Kakaras, E.C.; Giakoumis, E.G. \& Papagiannakis, R.G. (2010b) Investigation of the performance and emissions of bus engine operating on butanol/diesel fuel blends, Fuel, Vol. 89, No. 10, pp. 2781-2790, ISSN 0016-2361

Ramey, D. \& Yang, S.-T. (2004) Production of butyric acid and butanol from biomass, In: Final report to the US Department of Energy DE-F-G02-00ER86106, February 27, 2011, Available from:

http:/ /74.125.155.132/scholar?q=cache:BqatEryJKOwJ:scholar.google.com/+author: $\% 22$ Ramey $\% 22+$ intitle:\%22Production+of+butyric+acid+and+butanol+from+biomas s\%22+\&hl=cs\&as_sdt $=2000$

Ravagnani, A.; Jennert, K.C.B.; Steiner, E.; Grünberg, R.; Jefferies, J.R.; Wilkinson, S.R.; Young, D.I.; Tidswell, E.C.; Brown, D.P.; Youngman, P.; Morris, J.G.\& Young, M. (2000) Spo0A directly controls the switch from acid to solvent production in solvent-forming clostridia, Molecular Microbiology, Vol. 37, No. 5, pp. 1172-1185, ISSN 0950-382X

Rychtera, M.; Patakova, P.; Fribert, P.; Lipovsky, J.; Linhova, M.; Paulova, L.; Melzoch, K.\& Klefenz, H. (2010) Bottlenecks in bacterial production of fuel butanol, Proceedings of 19th International Congress of Chemical and Process Engineering, ISBN 978-80-02-02210-7, Prague, Czech Republic, September 2010

Sarathy, S.M.; Thomson, M.J.; Togbé, C.; Dagaut, P.; Halter, F. \& Mounaim-Rousselle, C. (2009) An experimental and kinetic modeling study of n-butanol combustion, Combustion and Flame, Vol. 156, No. 4, pp. 852-864, ISSN 0010-2180

Shaheen, R.; Shirley, M. \& Jones, D.T. (2000) Comparative fermentation studies of industrial strains belonging to four species of solvent-producing clostridia, Journal of Molecular Microbiology and Biotechnology, Vol. 2, No. 1, pp. 115-124, ISSN 1464-1801

Tomas, C.A.; Beamish, J.\& Papoutsakis, E.T. (2004) Transcriptional analysis of butanol stress and tolerance in Clostridium acetobutylicum, Journal of Bacteriology, Vol. 186, No. 7, pp. 2006-2018, ISSN 0021-9193

Tracy, B.P.; Gaida, S.M.\& Papoutsakis, E.T. (2008) Development and application of flowcytometric techniques for analyzing and sorting endospore-forming clostridia, Applied and Environmental Microbiology, Vol. 74, No. 24, pp. 7497-7506, ISSN 0099-2240 
United States Patent No.4539293 (1985) Production of butanol by fermentation in the presence of cocultures of clostridium, Application 1983-10-05

Wang, S.; Zhang, Y.; Dong, H.; Mao, S.; Zhu, Y.; Wang, R.; Luan, G. \& Li, Y. (2011) Formic acid triggers the acid crash of acetone-butanol-ethanol fermentation by Clostridium acetobutylicum, Applied and Environmental Microbiology, Vol. 77, No. 5, pp. 1674-1680, ISSN 0099-2240

Westhuizen van der, A.; Jones, D.T. \& Woods, D.R. (1982) Autolytic activity and butanol tolerance of Clostridium acetobutylicum, Applied and Environmental Microbiology, Vol. 44, No.6, pp. 1277-1281, ISSN 0099-2240

Wolf, L. (2007) 1-Butanol as a Gasoline Blending Biocomponent, Mobile Sources Technical Review Subcommittee - March 28, 2007 Meeting, Aarlington, USA, available from http://www.epa.gov/oar/caaac/mstrs/March2007/Wolf.pdf

Yacoub, Y.; Bata, B. \& Gautam, M. (1998) The performance and emission characteristics of $\mathrm{C}_{1^{-}}$ $\mathrm{C}_{5}$ alcohol-gasoline blends with matched oxygen content in a single-cylinder spark ignition engine, Proceedings of the Institution of Mechanical Engineers. Part A. Journal of Power and Energy, Vol. 212, No. 5, pp. 363-379, ISSN 0957-6509

Yao, M.; Wang H.; Zheng Z. \& Yue, Y. (2010) Experimental study of n-butanol additive and multi-injection on HD diesel engine performance and emissions, Fuel, Vol. 89, No. 9, pp. 2191-2201, ISSN 0016-2361

Xiaolong, Y; Jing, Y.; Tieping, L. (2009) The Effect of an SI Engine Using Butanol-Gasoline Blended Fuel on Performance and Enviroment, ICEET '09 Proceedings of the 2009 International Conference on Energy and Environment Technology - Volume 01, pp. 402-405, ISBN: 978-0-7695-3819-8 IEEE Computer Society Washington, DC, USA, 2009

Zverlov, V.V.; Berezina, O.; Velikodvorskaya, G.A. \& Schwartz, W.H. (2006) Bacterial acetone and butanol production by industrial fermentation in the Soviet Union: use of hydrolyzed agricultural waste for biorefinery, Applied Microbiology and Biotechnology, Vol. 71, No. 5, pp. 587-597, ISSN 0175-7598 


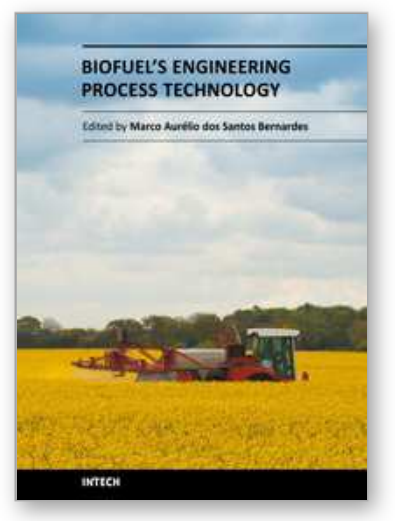

\author{
Biofuel's Engineering Process Technology \\ Edited by Dr. Marco Aurelio Dos Santos Bernardes
}

ISBN 978-953-307-480-1

Hard cover, 742 pages

Publisher InTech

Published online 01, August, 2011

Published in print edition August, 2011

This book aspires to be a comprehensive summary of current biofuels issues and thereby contribute to the understanding of this important topic. Readers will find themes including biofuels development efforts, their implications for the food industry, current and future biofuels crops, the successful Brazilian ethanol program, insights of the first, second, third and fourth biofuel generations, advanced biofuel production techniques, related waste treatment, emissions and environmental impacts, water consumption, produced allergens and toxins. Additionally, the biofuel policy discussion is expected to be continuing in the foreseeable future and the reading of the biofuels features dealt with in this book, are recommended for anyone interested in understanding this diverse and developing theme.

\title{
How to reference
}

In order to correctly reference this scholarly work, feel free to copy and paste the following:

Petra Patakova, Daniel Maxa, Mojmir Rychtera, Michaela Linhova, Petr Fribert, Zlata Muzikova, Jakub Lipovsky, Leona Paulova, Milan Pospisil, Gustav Sebor and Karel Melzoch (2011). Perspectives of Biobutanol Production and Use, Biofuel's Engineering Process Technology, Dr. Marco Aurelio Dos Santos Bernardes (Ed.), ISBN: 978-953-307-480-1, InTech, Available from: http://www.intechopen.com/books/biofuel-sengineering-process-technology/perspectives-of-biobutanol-production-and-use

\section{INTECH}

open science | open minds

\author{
InTech Europe \\ University Campus STeP Ri \\ Slavka Krautzeka 83/A \\ 51000 Rijeka, Croatia \\ Phone: +385 (51) 770447 \\ Fax: +385 (51) 686166 \\ www.intechopen.com
}

\author{
InTech China \\ Unit 405, Office Block, Hotel Equatorial Shanghai \\ No.65, Yan An Road (West), Shanghai, 200040, China \\ 中国上海市延安西路65号上海国际贵都大饭店办公楼405单元 \\ Phone: +86-21-62489820 \\ Fax: +86-21-62489821
}


(C) 2011 The Author(s). Licensee IntechOpen. This chapter is distributed under the terms of the Creative Commons Attribution-NonCommercialShareAlike-3.0 License, which permits use, distribution and reproduction for non-commercial purposes, provided the original is properly cited and derivative works building on this content are distributed under the same license. 